\title{
The Influence of Different Type of Aggregate, Fly Ash and Fiber Reinforced Polymer on Splitting Resistance in Pretensioned Concrete Railroad Ties
}

\author{
Adrijana Savic ${ }^{1 *}$, Robert J. Peterman ${ }^{1}$ \\ 1 Department of Civil Engineering, Kansas State University, Manhattan (Kansas, USA)
}

This research evaluates the influence of the different types of concrete mixture, using a shallow type of indentation of wire, having the different edge distance and compressive strength of concrete on splitting resistance in pr-etensioned concrete railroad sleepers. The investigated compressive strength of concrete was 4500psi. The research was experimental, and the part of this research was formally adapted in Arema Standards for Railway Engineering Chapter 30 section 4.2.4.

Keywords: Heavy machinery, Mechanical engineering, Civil engineering

\section{INTRODUCTION}

This research is focused on longitudinal splitting which occurs in prestressed concrete members due to different variables such as concrete mixture, wire type, and release strength of concrete. The goal is to find the best possible design parameters to diminish longitudinal splitting in prestressed concrete members. Different prestressed concrete prisms were examined having different cross-sections using different concrete mix ture and compressive strength. The examined wire type which will be described in this paper is denoted as "WB" wire type, which belongs to the chevron type of wire. The research which was conducted at Kansas State Univ ersity used this wire type having lin edge distance and experiments with this wire were successful without longitudinal splitting in prestressed concrete members. The influence of variables was presented in the research of Bodapati [1], Savic et al [2], [3], [4], [5], [6]. They investigated the influence of edge distance and wire type indentation on longitudinal splitting. According to their research, the minimum edge distance depends on the wire type and for shallow wire type, it will be 0.75 in.

\section{METHODOLOGY}

\subsection{Splitting Crack Evaluation}

Three prisms having different cross-sections were cast at a time. The values of edge distances were $3 / 4$ in, $5 / 8 \mathrm{in}$, and 1/2in. Different concrete mixes were designed so that the most effective factors were included. These factors are angularity, coarseness, the volume of coarse aggregate, class $\mathrm{F}$ fly ash, and w/cm ratio. In addition, 5 mixes were designed to assess the effect of transverse reinforcement on splitting cracks. The compressive strength of concrete was $4500 \mathrm{psi}$ for each prism and the water/cement ratio was 0.32 . Adva Cast 530 was used as a water reducer.

\subsection{WB Wire Type}

WB wire Type belongs to chevron type of wires, but during this research and after all experimental investigation this wire had performance remarkably similar to wires which belong to deep chevron wire type. The physics behind this splitting is still unknown and the VOLPE center is working on a numerical approach to find the reason for such behaviour. The geometry of the prestressing wire indents is a significant variable in the formation of longitudinal splitting cracks in pre-tensioned concrete members. Longitudinal splitting along prestressing tendons can result in severe splitting and complete tie failure in the field under normal train loading over time. Features of interest for each wire type are indent depth, indent volume, indent sidewall area, indent sidewall angle, indent length, indent pitch period, indent width, indent distance, and indent orientation angle. Figure 1 shows graphically the indent features of wires [2].

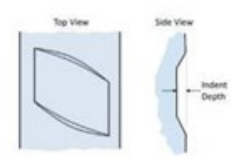

(a) Indent Depth

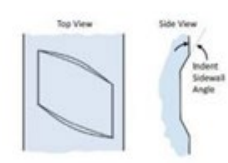

(d) Indent Sidewall Angle

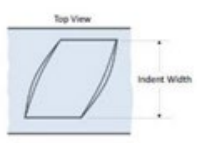

(g) Indent Width

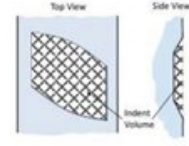

(b) Indent Volume

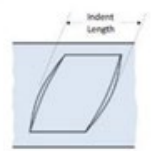

(e) Indent Length

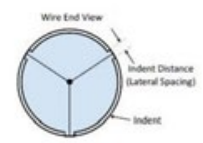

(h) Indent Distance

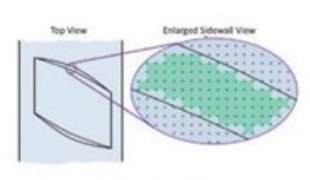

(c) Indent Sidewall Area

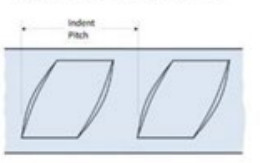

(f) Indent Pitch

(i) Indent Orientation Angle

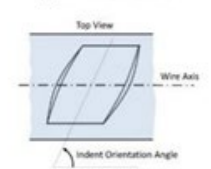

Figure 1: The indent Features of wires 
Table 1: Indented wire Measurements

\begin{tabular}{|l|l|l|l|l|}
\hline & $\begin{array}{l}\text { Average } \\
\text { depth } \\
(\mathrm{mm})\end{array}$ & $\begin{array}{l}\text { Edge } \\
\text { Wall } \\
\text { angle } \\
(\text { degree })\end{array}$ & $\begin{array}{l}\text { Side } \\
\text { Wall } \\
\text { Area } \\
\left(\mathrm{mm}^{2}\right)\end{array}$ & $\begin{array}{l}\text { Volume } \\
\left(\mathrm{mm}^{3}\right)\end{array}$ \\
\hline WB & 0.119 & 16.45 & 2.92 & 1.696 \\
\hline
\end{tabular}

Figure 2 presents WB Wire Type Microscope Image and 3D Model [8].

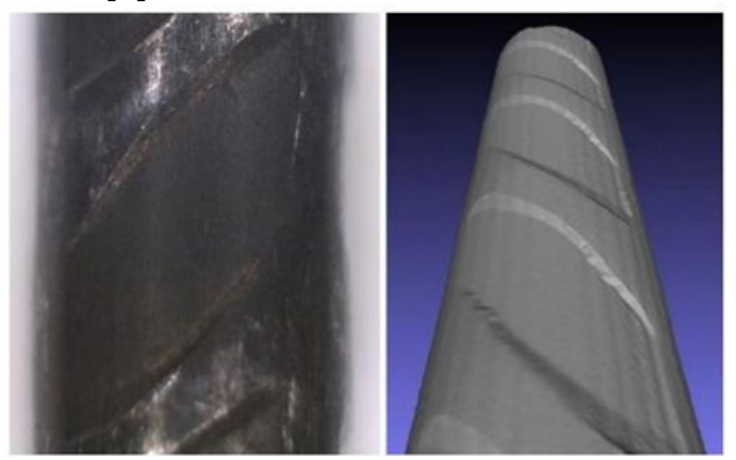

Figure 2: WB Wire Type-Microscope Image and $3 D$ Model (8)

\subsection{Sample preparation}

Three prisms having different edge distances were cast at a time. The edge distance is defined as a distance from the tendon center to the edge of the prism. Four prisms were embedded into each cross-section having a common distance of $2 \mathrm{in}$. Three different values of edge distances were examined 3/4in, 5/8in, and 1/2in.

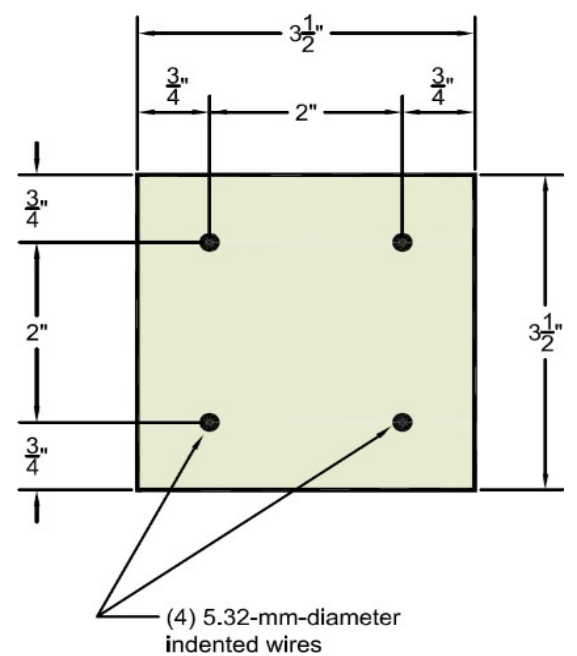

Before the casting procedure, each wire was pulled to $7000 \mathrm{lbs}$. The average initial compressive stress for edge distance $3 / 4$ in was equal to $28000 \mathrm{lb}$. $/(3.5 \mathrm{in}) 2=2285 \mathrm{psi}$. For prisms with a $5 / 8$ in edge distance, the value of stress was: $28000 \mathrm{lb}$. / (3.25 in) $2=2650$ psi which was $59 \%$ of the 4500-psi concrete release strength. For prisms with $1 / 2$ in edge distance, the average initial compressive stress was it was 3110 psi, which was approximately $89 \%$ of the 4500-psi concrete release strength. This value is significantly into the nonlinear range of the concrete. In the pre-tensioning frame, wires within each prism were tensioned between two abutments before the casting of concrete. A jacking assembly was created at Kansas State University and used for this study. The mechanical gear jack was attached to the metal frame which allowed gradual tensioning and release operations. Jacking of the steel prestressing wires occurred at the end of the steel frame referred to as the "Live End" as shown in Figure 4. Figure 5 shows a prestressed concrete bed with three sets of prisms having differentedge distances.

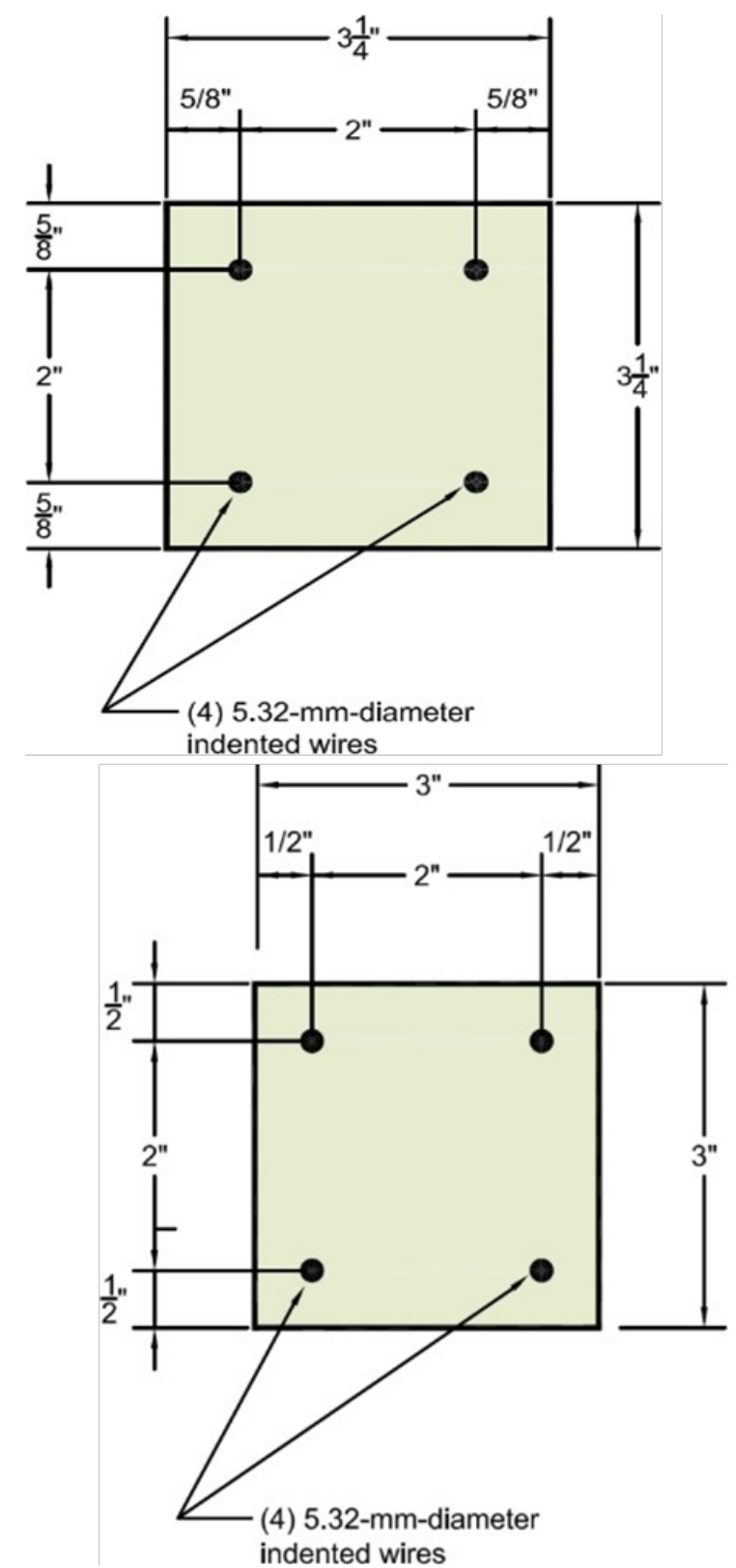

Figure 3: Cross-section of three prisms for each set of prisms

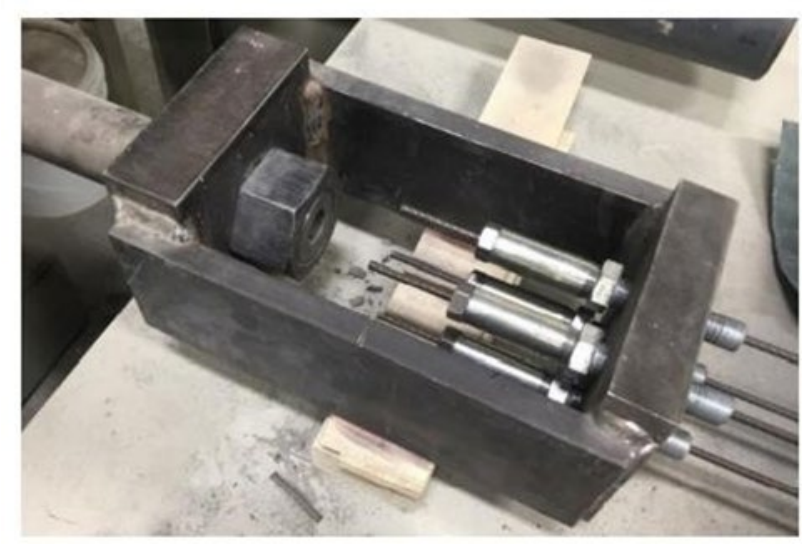


Figure 4: Prestressed Jacking Arrangement at the Live End

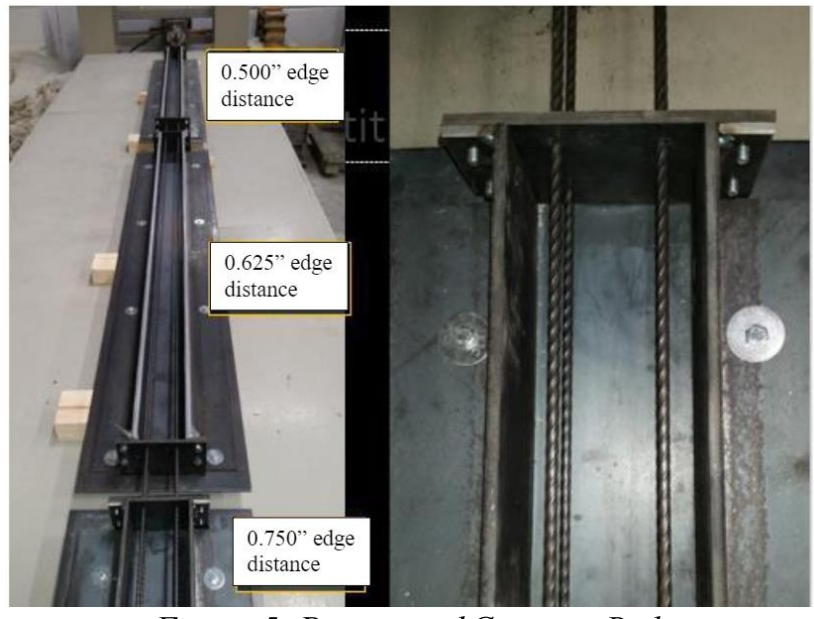

Figure 5: Prestressed Concrete Bed

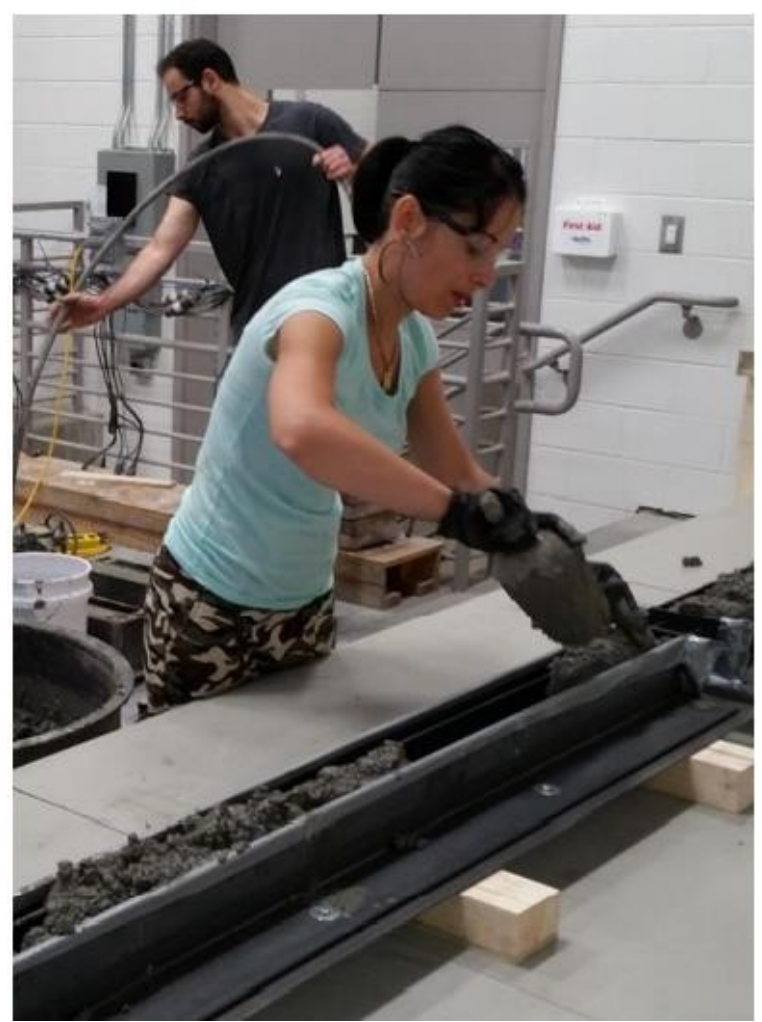

Figure 6: Casting the Prestressed Concrete Prisms

\subsection{Test Procedure}

After casting specimens, temperature-match cured cylinders were tested at periodic intervals to determine the compressive strength. As soon as the cylinders reached 4500 psi (approximately after eight hours, depending on the lab temperature), the prisms were gradually detensioned. For prestressed concrete railroad ties to function sufficiently in the field, and to guarantee safety, the prestressing force must be fully introduced into the railroad tie at a location well before the rail load is applied. The length needed to transfer the prestress force in to the concrete member is well known as the "Transfer length". The laser-speckle device was used to scan the top surface of a concrete prism before and after de-tensioning, and automatically plot the strain profile and determine the transfer length using a least-squares algorithm [9].

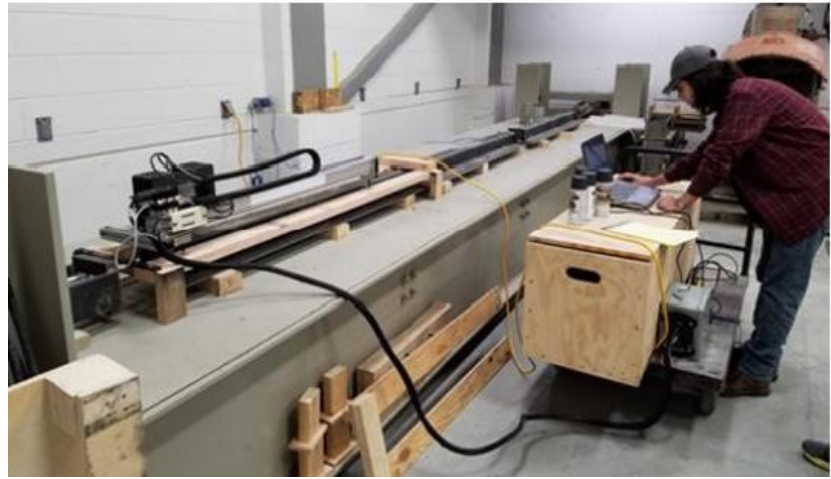

Figure 7. Measuring the Transfer Lengths

Two scans are required for transfer length measurement one before de-tensioning and one after the cutting operation after the de-tensioning procedure. The surface strain was calculated and plotted automatically after the raw images are captured.

Each prism provided two measurements of transfer lengths(live and dead-end) and provided ap proximately eight independent splitting tests of edge distance (fourwire cover tests on each end) for a given release strength. [2]

The length and width of cracks were measured using a ruler and concrete crack comparator respectively, after 90 days. This time delay was used to evaluate long term creep behavior of splitting cracks. In some cases, the longitudinal splitting occurred immediately after the detensioning procedure but due to lateral sustained stres ses, some cracks appeared after several weeks. All cracks were marked using a permanent red marker. For further investigations crack length for each prism was determined along with the values of Crack Areas. The crack area was defined as crack width multiplied with crack length. In the case where spalling occurred the arbitrary value of crack width was used as $2 \mathrm{in}$.

\section{RESULTS}

3.1. WB wire type 4500psi using Crushed Gravel as aggregate.

WB wire type which belongs to the chevron type of wire was examined using different concrete mixtures to understand which variable is most important in transferring the stresses between steel and concrete. Mix\#1 used Crushed Gravel as aggregate, Adva Cast 530 as High Range Water Reducer, and water/cement ratio was 0.32 for all set of prisms. Table 2 shows the concrete mix ingredients.

Table 2: Concrete Mix Design Using Crushed Gravel as Aggregate

\begin{tabular}{|l|l|}
\hline Material & Weight $\left(\mathrm{lbs} . / \mathrm{yd}^{3}\right)$ \\
\hline Cement & 813.8 \\
\hline Water & 260.4 \\
\hline Large Crushed Gravel & 897.8 \\
\hline Small Crushed Gravel & 538.7 \\
\hline Sand & 1436.5 \\
\hline Adva Cast 530 & $81 \mathrm{fl} . \mathrm{oz} . / \mathrm{yd}^{3}$ \\
\hline
\end{tabular}


Figure 8 shows a set of prisms after the de-tensioning procedure on the dead-end of the prestressed bed (Dead end stress operations did not occur). Spalling was noticed on the prism having $1 / 2$ in edge distance.

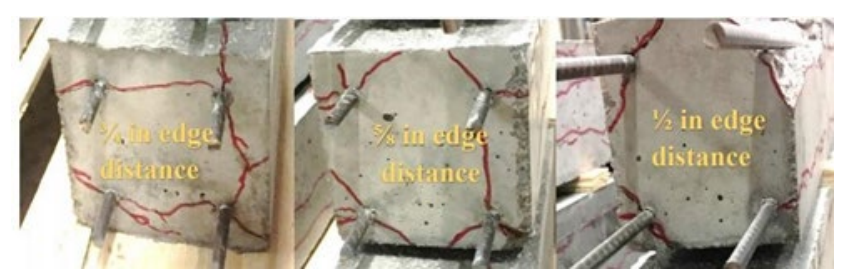

Figure 8: Observed Cracking

Figures 9 and 10 present Crack Area and Crack Length respectively as a function of the edge distance of the prisms. With reducing the values of edge distance more cracks appeared, and crack lengths are higher.

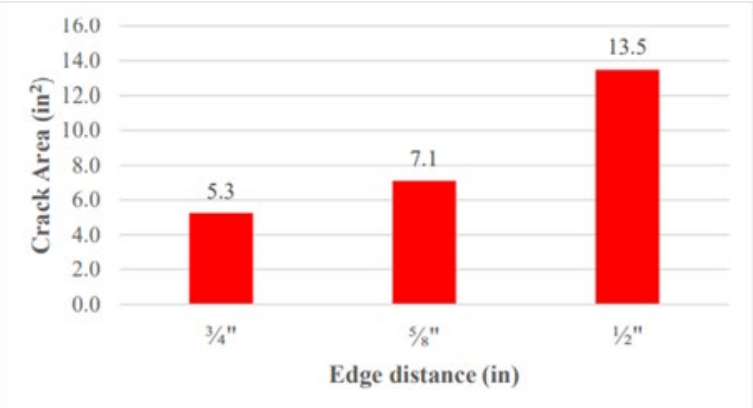

Figure 8: CrackArea $\left(\mathrm{in}^{2}\right)$

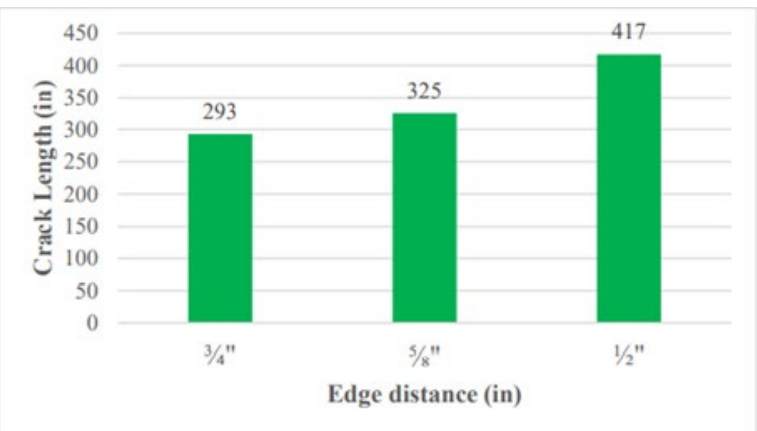

Figure 9: CrackLength

\subsection{WB wire Type using Mix\#2}

Mix design number 2 used Granite as aggregate and Table 3 shows the mix properties.

Table 3: Concrete Mix Design Used Granite as Aggregate

\begin{tabular}{|c|c|}
\hline Material & $\begin{array}{c}\text { Weight } \\
\text { Lbs } / \mathrm{yd}^{3}\end{array}$ \\
\hline Cement & 813.8 \\
\hline Water & 260.4 \\
\hline Crushed Granite & 1447 \\
\hline Sand & 1447 \\
\hline Adva Cast 530 & $81 \mathrm{fl.oz} / \mathrm{yd}^{3}$ \\
\hline
\end{tabular}

Figure 11 shows the longitudinal strain profile for the prism having $3 / 4$ in edge distance. The values for transfer lengths are enormous. This results from the large magnitudes of longitudinal surface strain that go along with longitudinal splitting of the prism. The values of transfer lengths imply that wire type WB exhibits poor performance.

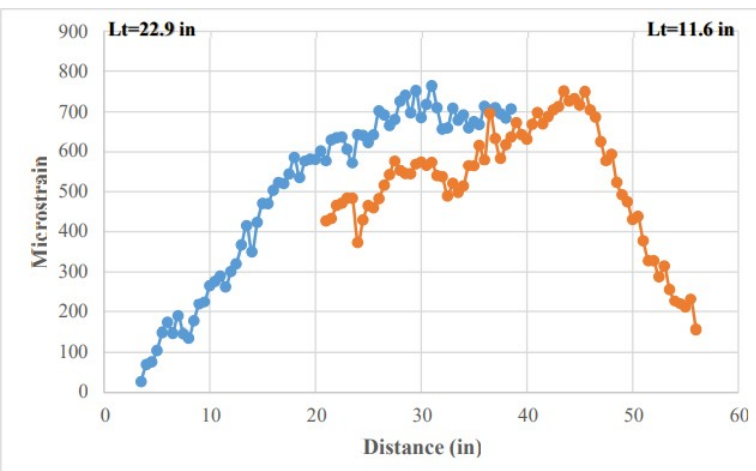

Figure 11: Longitudinal Strain Profile

The average crack width was 0.02 in and the average crack length was approximately $15 \mathrm{in}$.

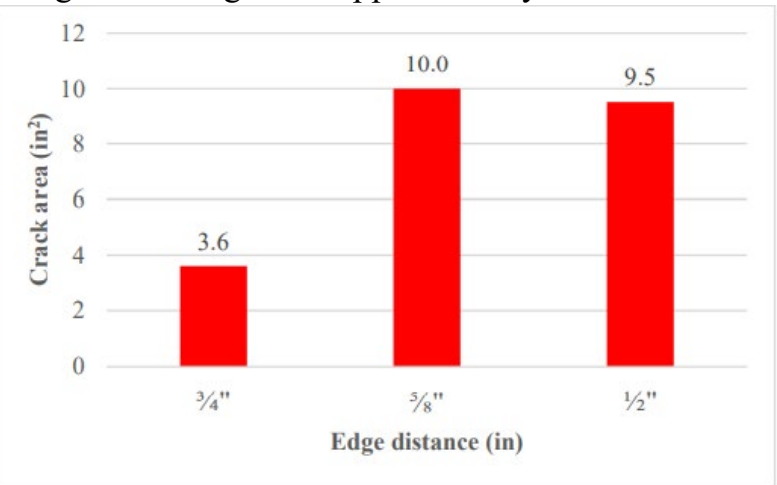

Figure 12: CrackArea

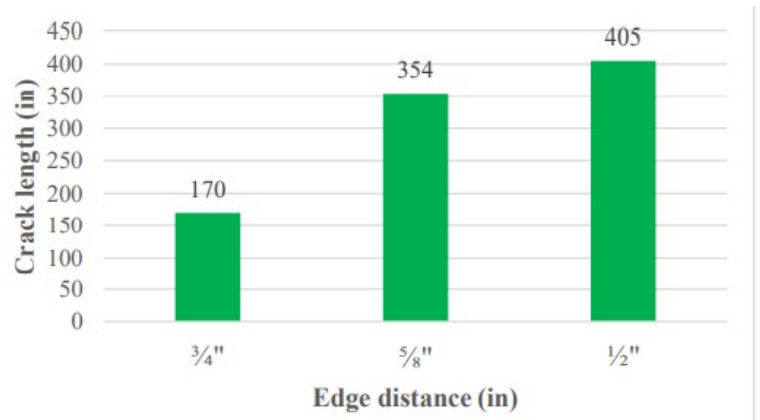

Figure 13: Cracklength

According to Figures 12 and $13 \mathrm{WB}$ wire type performed better using Granite in comparison to crushed gravel.

\subsection{WB wire Type using Mix \#3}

Mix Design \#3 had uncrushed local Pea Gravel and had poor performance resulting in high values of crack areas and crack lengths as shown in Figures 14 and 15.

\begin{tabular}{|l|l|}
\hline Material & $\begin{array}{l}\text { Weight } \\
\left(\mathrm{lbs} / \mathrm{yd}^{3}\right)\end{array}$ \\
\hline Cement & 780 \\
\hline Water & 249.6 \\
\hline $\begin{array}{l}\text { Uncrushed } \\
\text { Gravel }\end{array}$ & 1526 \\
\hline Sand & 1526 \\
\hline Adva Cast 530 & $81 \mathrm{fl.oz} / \mathrm{yd}^{3}$ \\
\hline
\end{tabular}

The maximum crack width on the live end of the prism with a $3 / 4$ in edge distance was 0.05 in and the maximum crack length was $32 \mathrm{in}$. On the other side, the maximum crack width was $0.04 \mathrm{in}$ and the maximum crack length was $27 \mathrm{in.}$ 


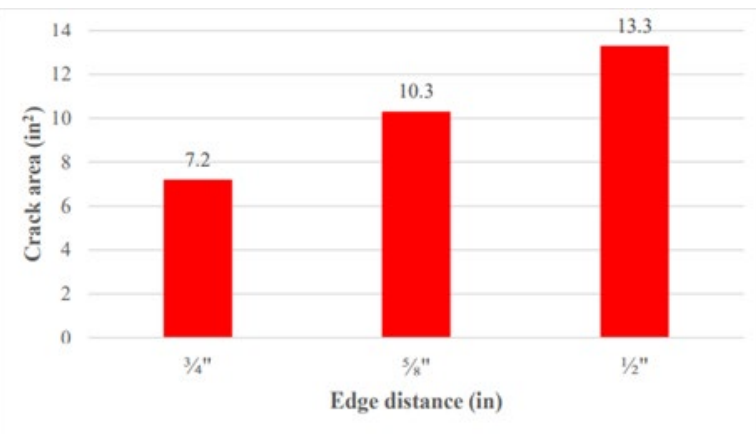

Figure 14: Crack Area

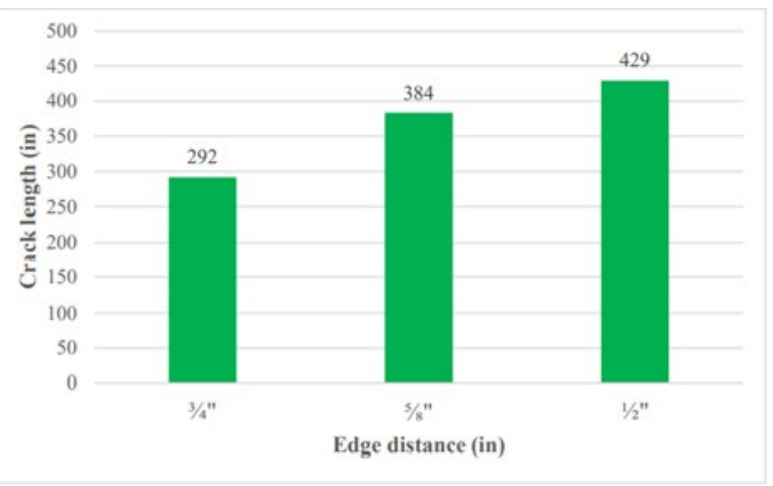

Figure 15: Crack Length

\subsection{WB wire Type using Mix \#4}

To diminish the crack lengths and crack areas in prisms using WB wire type in Mix\#1 25\% fly ash replacement was added. According to the results shown in Figure 16, adding fly ash into the mixture has a slight effect on 3/4in.-edge distance prisms. Overall, the substitution of fly ash negatively affects prisms in terms of splitting cracks.

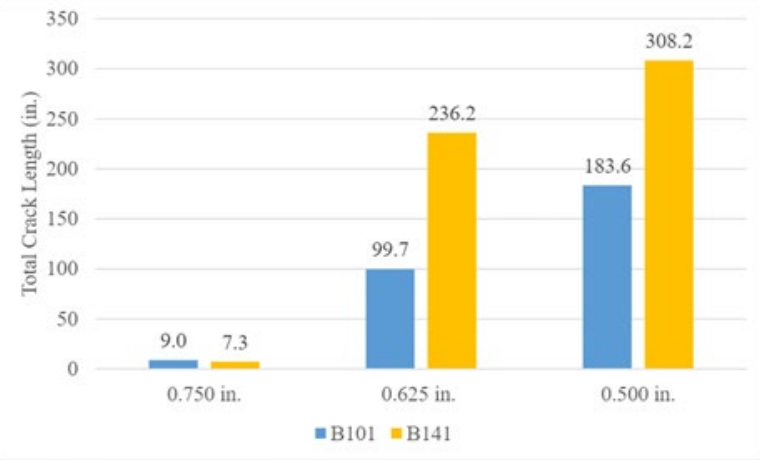

Figure 16: Crack length measurements for prisms with 0 and $25 \%$ Fly ash

\subsection{Effect of Fiber Reinforcement}

During the years of research, it was wellestablished that reinforcing concrete can lead to a greater crack resistance [10], [11]. To improve the mechanical properties of concrete material, polymer fibers have been widely used with different percentages.

To increase the mechanical properties of the concrete a monofilament polypropylene micro-fiber was also added to the concrete of a select number of prestressed prisms. This Fiber complied with ASTM C 1116, Standard Specification for Fiber Reinforced Concrete and Shotcrete.

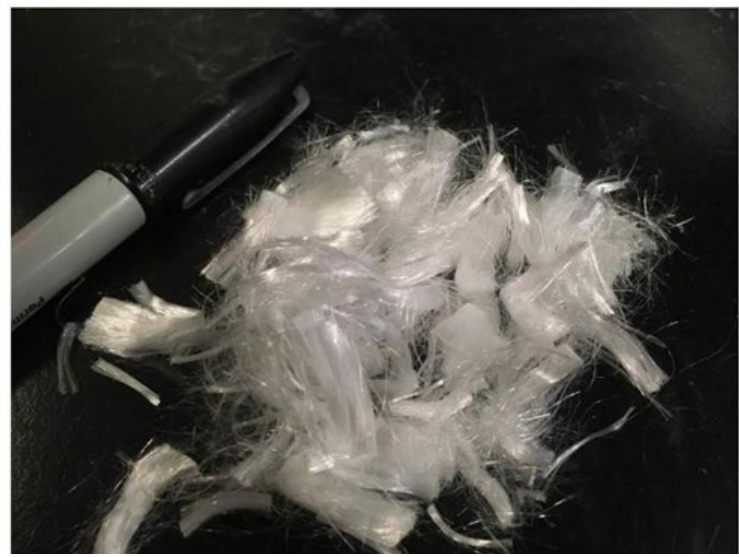

Figure 17: Polymer Fiber [10]

Polymer Fiber of 5\% was added to Mix\#3 and according to experimental investigation, it was concluded that better results were achieved. The number of detectable cracks declined by more than $30 \%$ when polymer fiber was used. However, the number of splitting cracks was reduced at $1 / 2$-in. edge distance.

There is a significant improvement in crack propagation resistance when polymer fiber is used.

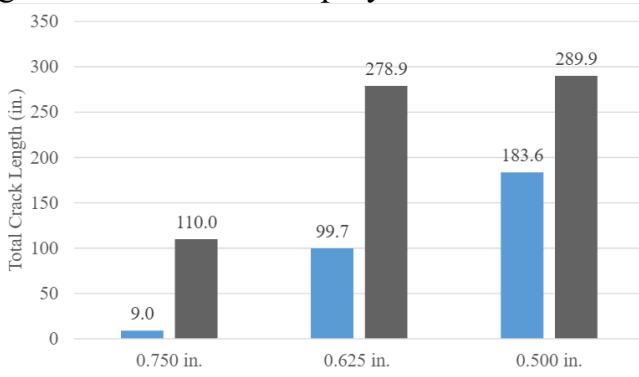

Figure 18: Crack length measurements for prisms with $0 \%$ and $5 \%$ polymer fiber

Figure 18 shows the crack length measurements using WB wire type and concrete mixture \#3 with fiber polymer.

\section{CONCLUSIONS AND RECOMMENDATIONS}

Based on the results of this study, the following four primary conclusions are drawn.

- The edge distance is the most significant parame ter to prevent longitudinal splitting in prestressed concrete members. According to previous research conducted at Kansas State University by Naga Bodapati, WB wire type did not split having 1 in tendon edge distance.

- The second significant parameter is the wire indent characteristics. According to research conducted by A. Savic [3], [4], [5] the shallow chevron type of wires did not split on the prisms having 3/4in edge distance. The indent wire type affects the edge distance, according to all results the minimum edge distance for WB wire type anddeep chevron wire types is $1.25 \mathrm{in}$.

- The third important parameter which affects longitudinal splitting is a concrete mix ture. Concrete mix using fiber polymer showed the best performance and increase splitting resistance. Fly ash in concrete mixture had a negative impact on splitting resistance. 
- The fourth important parameter is concrete maturity at the time of the de-tensioning procedure. In this research 4500psi compressive strength was ex amined since that all prestressed concrete tie manufacturer detensioningprocedure commenced at that time. Higher compressive strengths at the transfer of prestressing also correspond to a higher Modulus of Elasticity (MOE). The higher MOE causes increased lateral stresses and serve to diminish much of the benefit aspect of the increased tensilestrength.

\section{REFERENCES}

[1] Bodapati, N. B., Peterman, R. J., Zhao, W., Wu, C.-H. J., Beck, B. T., Haynes, M., \& Holste, J. (2013). Influence of Indented Wire Geometry and Concrete Parameters on the Transfer Length in Prestressed Concrete Crossties. 2013 Joint Rail Conference. Knoxville, TN: American Society of Mechanical Engineers.

[2] Savic, Adrijana, "Developing a prism qualification test to ensure adequate splitting resistance in pretensioned concrete railroad ties" Thesis, Kansas State University

[3] Savic, A, Beck, BT, Robertson, AA, Peterman, RJ, Clark, J, \& Wu, C(. "Effects of Cover, Compressive Strength, and Wire Type on Bond Performance in Prismatic Prestressed Concrete Members." Proceedings of the 2018 Joint Rail Conference. 2018 Joint Rail Conference. Pittsburgh, Pennsylvania, USA. April 1820,2018. V001T01A007. ASME. https://doi.org/10.1115/JRC2018-6153

[4] Savic, A, Beck, BT, Shafiei Dastgerdi, A, Peterman, RJ, Riding, K, \& Robertson, AA. "The Effect of Wire Type on Cracking Propensity in Prestressed Concrete Prisms." Proceedings of the 2019 Joint Rail Conference. 2019 Joint Rail Conference. Snowbird, Utah, USA. April 9-12, 2019. V001T01A002. ASME. https://doi.org/10.1115/JRC2019-1234

[5] Beck, BT, Robertson, AA, Peterman, RJ, Savic, A, $\mathrm{Wu}$, CJ, Riding, KA, \& Bloomfield, J. "A High Resolution Automated Prestressing Wire Indent Profiling System for Verification of Wire-Concrete Mix Compatibility."Proceedings of the 2019 Joint Rail Conference. 2019 Joint Rail Conference. Snowbird, Utah, USA. April 9-12, 2019.V001T01A009. ASME. https://doi.org/10.1115/JRC2019- 1269

[6] Shafiei Dastgerdi, A, Savic, A, Peterman, RJ, Riding, K, \& Beck, BT. "Evaluation of Splitting Crack Propagation in Pre-Stressed Concrete Ties Made With Different Types of Coarse Aggregate." Proceedings of the 2019 Joint Rail Conference. 2019 Joint Rail Conference. Snowbird, Utah, USA. April 9-12, 2019. V001T01A015.

ASME. https://doi.org/10.1115/JRC2019-1280

[7] Aref Shafiei Dastgerdi,Robert J. Peterman,Adrijana Savic,Kyle Riding,B. Terry Beck, Prediction of splitting crack growth in prestressed concrete members using fracture toughness and concrete mix design"
Elsevier Construction and Building Materials, 20 June 2020

[8] Savić A, Dastgerdi AS, Beck T, Peterman RJ, Robertson A. The Influence of Concrete Cover, Type of Wire Indentation and Concrete Mix on Bond between Steel and Concrete in Prismatic Prestressed Concrete Members. AEF 2021;39:103-26.

[9] Shafiei Dastgerdi, A, Savic, A, Peterman, RJ, Riding, K, \& Beck, BT. "Evaluation of Splitting Crack Propagation in Pre-Stressed Concrete Ties Made With Different Types of Coarse Aggregate." Proceedings of the 2019 Joint Rail Conference. 2019 Joint Rail Conference. Snowbird, Utah, USA. April 9-12, 2019. V001T01A015. https://doi.org/10.1115/JRC2019-1280

ASME.

[10] Aref Shafiei, "Effect of concrete composition on splitting-cracks in prestressed concrete railroad ties: Application of fracture mechanics", Thesis, Kansas State University

[11] Mustafa M.Raheem et al. "Development of an objective model to predict shear capacity of FRP Uwrap anchors" Composite Structures Volume 265, 1 June 2021, 113762

https://doi.org/10.1016/j.compstruct.2021.113762

[12] Shafiei, A, Riding, KA, Peterman, RJ, Christensen, C, Beck, BT, Robertson, AA, \& Wu, CJ. "Suitability and Variability of Non-Destructive Testing Methods for Concrete Railroad Tie Inspection." Proceedings of the 2016 Joint Rail Conference. 2016 Joint Rail Conference. Columbia, South Carolina, USA. April 12-15, 2016. V001T01A020. ASME. https://doi.org/10.1115/JRC2016- 5776

Uticaj različitih vrsta agregata, letećeg pepela i polimera ojačanog vlaknima na otpornost na kidanje u prethodno zategnutim betonskim železničkim vezama
Adrijana Savić ${ }^{*}$, Robert J. Peterman ${ }^{1}$
${ }^{1}$ Odsek za građevinarstvo, Državni univerzitet Kanzas, Menhetn (Kanzas, SAD)

Ovim istraživanjem procenjuje se utic aj različitih tipova betonske mešavine, korišćenjem plitkog tipa udubljenja žice, različitog rastojanja ivica i čvrstoće betona na granicu kidanja u prednapregnutim betonskim železničkim pragovima. Ispitana čvrstoća betona bila je 4500 psi. Istraživanje je bilo eksperimentalno, a deo ovog istraživanja je formalno adaptiran u Arema Standards for railway Engineering Chapter 30 section 4.2.4.

Ključne reči: Teške mašine, Mašinstvo,
Građevinarstvo

